\title{
Batik Solo Trans (BST) as Tourist Transportation and Integrated Payment System Preference that Supports the Tourism Sector in Surakarta City
}

\author{
RA Dinasty Purnomoasri \\ Department of Civil Engineering, Tunas Pembangunan University, Surakarta, Indonesia \\ dinasty@lecture.utp.ac.id \\ Reki Arbianto \\ Department of Civil Engineering, Tunas Pembangunan University, Surakarta, Indonesia \\ reki.arbianto@lecture.utp.ac.id
}

\begin{abstract}
Surakarta City is one of the tourist destinations in Indonesia with the existence of historical places such as the Keraton Surakarta, Pura Mangkunegaran and historical museums. Batik Solo Trans (BST), a public transportation launched by Surakarta City government, which is considered to be the choice of transportation used by tourists. This study aims to identify BST routes to determine whether BST can be used as tourist transportation and whether the available payment system supports the tourism sector in Surakarta City. The method used is the literature review method and descriptive analysis of the description of the questionnaire survey of tourists. The result states that the BST route with 4 active corridors from 8 planned corridors covers most of the historical tourist attractions in Surakarta City and the preference of the tourist payment system is $58.33 \%$ using electronic money cards for BST ticket payments supported by a non-cash card service system that is re-used after being dismissed inefficient.
\end{abstract}

\section{Keywords: Batik Solo Trans, BST, Tourism, Tourist Transportation, BRT, Surakarta City}

\section{Introduction}

Surakarta city or Solo city has become one of the cities tourist destinations in Indonesia. This is because the existence of historical places that are tourist destinations such as the Keraton Surakarta which is the source of traditional events and the cultural centre of Surakarta still exist today, Pura Mangkunegaran, Museum Radya Pustaka, Museum of Keris, Gedhe Traditional Market, Klewer Traditional Market and many more as well as places that are commonly used as culinary tours. Given the potential for rapid development in the tourism sector in Surakarta City, support from the transportation sector is certainly needed [Rizky Arif, 2019]. Transportation cannot be separated and is very much-needed by the public to meet their daily needs and needs, in other words, transportation is like the heart of society, especially in urban areas [Pratiwi D, et al, 2015 ]. Surakarta City is one of the cities in Central Java which functions as a National Activity Center (PKN). This role makes
Surakarta a destination for the hinterland area around it, which has an impact on increasing the intensity of internal movements and regional movements of Surakarta City [Tatralok Kota Surakarta, 2009 ].

The City Government (Pemkot) of Surakarta has launched a vision and mission for Surakarta City Towards a City with Sustainable Transportation. One of its work programs is to revitalize regular urban public transportation into public transportation with the Bus Rapid Transit (BRT) system which is realized in the form of Batik Solo Trans (BST) [Budi Yulianto, et al, 2017]. BST has great potential in supporting the tourism sector in Surakarta City so that it can optimally develop [Rizky Arif, 2019], considering that BST as public transportation that serves the people of Surakarta, the BST route also covers quite a several tourism object, hotels, restaurants and markets. This is further supported by the planning of BST as public transportation that is integrated with Solobalapan Station, Purwosari Station, 
Tirtonadi Bus station, and Adi Soemarmo Airport where connected public transportation can increase community mobility not only for the people of Surakarta itself but also support the mobility of tourists who come to travel in Surakarta City [Anandhika, 2019]. The purpose of the author is to see the potential of BST as a means of transportation for tourists who prefer to use public transportation by observing the tourist locations that are covered by the BST route and the preference of the BST payment system that supports the tourism sector in Surakarta City.

\section{Method}

The method used in this research is literature study from various sources used as secondary data and the distribution of questionnaires with the criteria chosen by tourists as respondents where respondents are taken randomly or using the random sampling method as the primary data. The analysis was carried out by looking at the BST route to record the tourist attractions covered by each BST route through the city map of Surakarta which is also supported by Google Maps and calculating the data from the questionnaire survey results to tourists for payment system preferences.

\section{Batik Solo Trans (BST)}

Surakarta City Government presents Batik Solo Trans or better known as BST as the provision of public transportation that indirectly supports the application of city branding in serving the needs of the public for transportation [Herdyanah Mustika, 2017]. BST was launched by the Mayor of Surakarta Joko Widodo on September 1, 2010, Initially, only two corridors were operating but now 4 active corridors out of the 8 planned corridors have been operated. BST, which is a BRT in Surakarta, sets the fare for public passengers to date at IDR 4,500 and for students (wearing uniforms) it is IDR 2,000 or the equivalent of 0.32 USD for public passengers and 0.14 USD for students wearing uniforms [Batik Solo Trans, 2020]. The scope of BST operations is not only within Surakarta City but also across regions such as Palur (Karanganyar Regency), Kartasura (Sukoharjo Regency), and Adi Sumarmo Airport (Boyolali Regency). The cooperation in BST services that is established by Surakarta City and its surroundings a form of public service in the transportation sector, this is supported by Law number 23 of 2014 concerning Regional Government of the Market 363 which states that to improve the welfare of the community, regions can cooperate by paying attention to efficiency and the effectiveness of mutually beneficial public services [Kristina Setyowati, 2017].

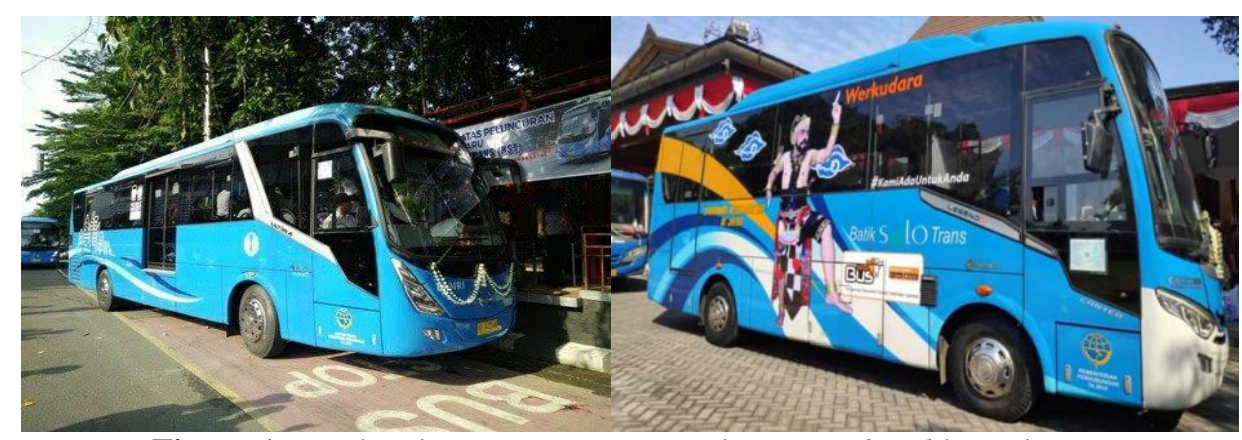

Figure 1: Batik Solo Trans (source Surakarta.go.id and kuasakata.com)

\section{Surakarta City Tourist Map}

Surakarta City has a long history to form a very distinctive cultural culture with the branding "Solo the spirit of java" which was designated as regional branding for 6 districts 1 Subosukowonosraten city through joint regulations with the mayor of Surakarta, the Regent of Sukoharjo, the Regent of Karanganyar, the Regent of Wonogiri, the
Regent of Sragen and the Regent of Klaten on 2 April 2008 regarding regional identity [Herdyanah Mustika, 2017]. This greatly supports the fast growing tourism sector in the city of Surakarta and its surroundings. Figure 3 shows a map of tourist locations around Surakarta, city and Figure 4 shows a tourist map of Surakarta city. To support tourism, geographic information system 
technology using smartphones is needed by tourists to find various important information, tourists in Surakarta city can download the "Solo Destination" application, which is the official application of Surakarta city, launched in 2014 by the Mayor of Surakarta, FX Hari Rudyatmo. Which was the beginning of the Solo Smart City program which has been developed since 2016. This application can provide various information about potential tourism for tourists such as culinary places, traditional shopping centers, and hotels. The advantage of this application is the ability to display information in real time, for example the Batik Solo Trans (BST) schedule [Monika Sri Y, 2017].

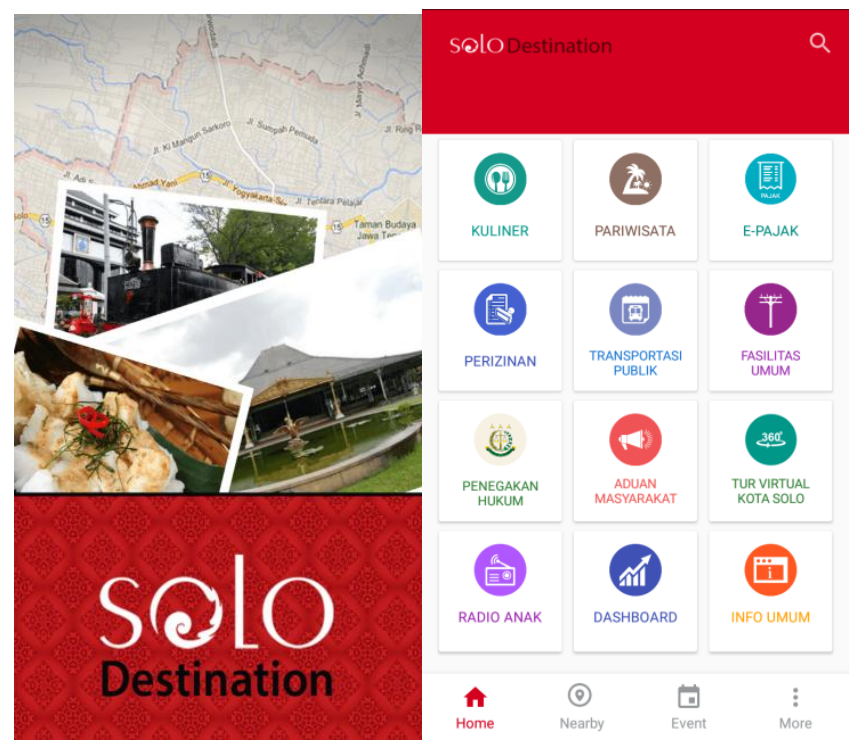

Figure 2: Solo Destination Application

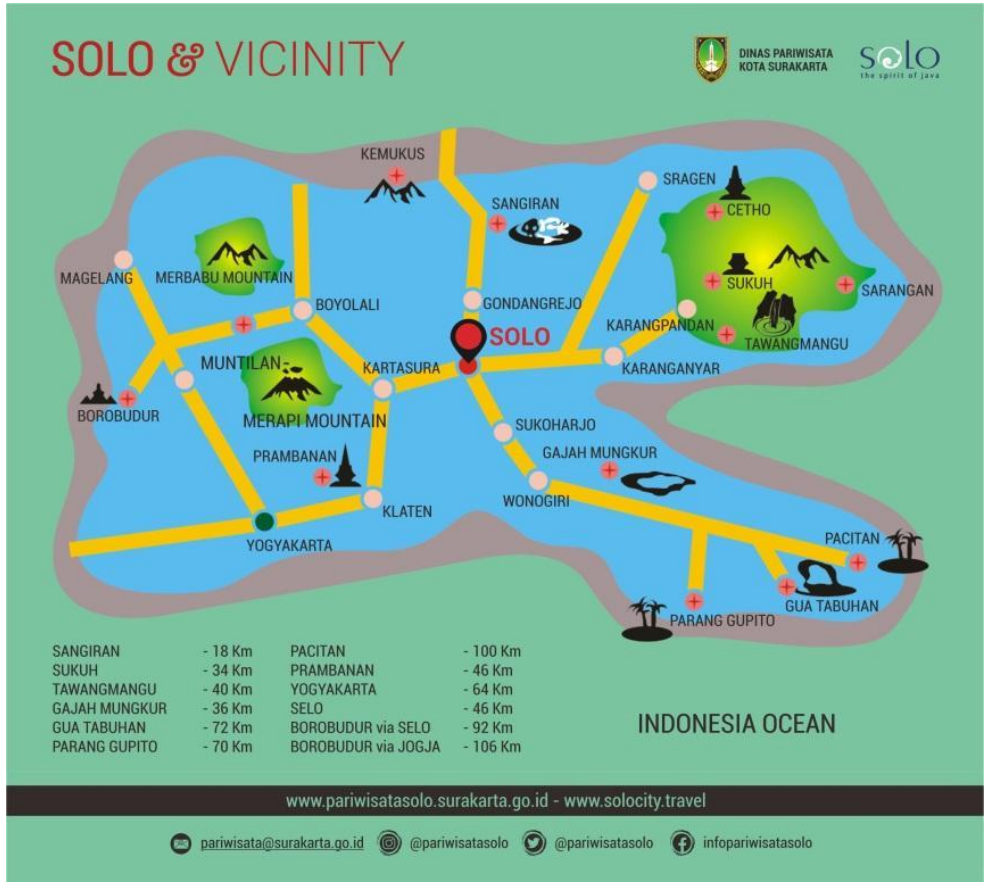

Figure 3: Tourist map around Surakarta / Solo (Surakarta City Tourism Office) 


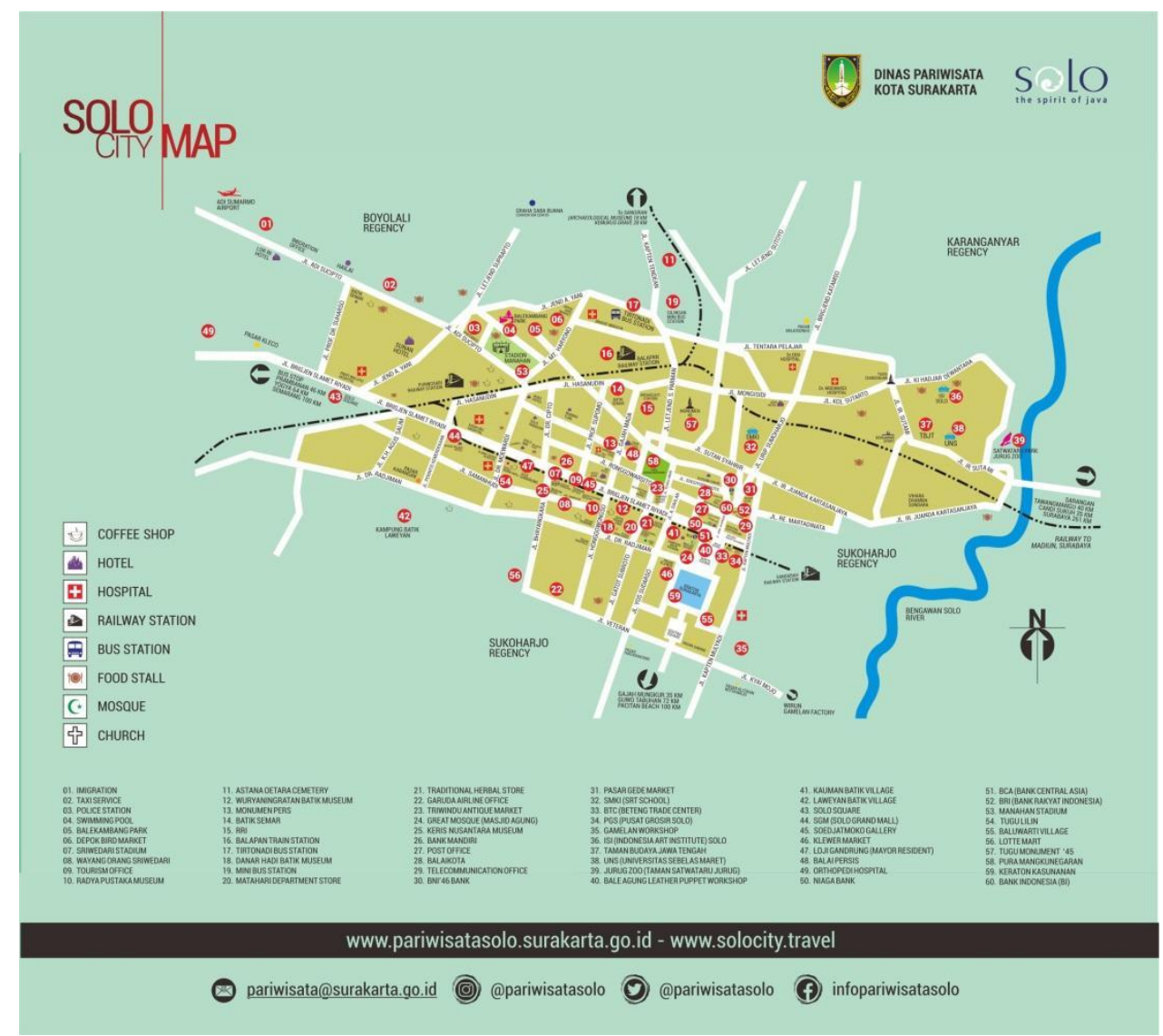

Figure 4: Surakarta City / Solo City Map (Surakarta City Tourism Office)

In this chapter, you can see Surakarta City tourism map in Figure 4. It can be seen that many locations can be visited by tourists in the city of Surakarta. Most of the tourist locations have been covered by the BST route and for more details will be explained in the next chapter.

\section{Batik Solo trans (BST) as Tourist Transportation}

Tourism is closely related to the transportation sector, which means that the main function of transportation is closely related to accessibility where transportation is expected to make it easier for users to visit certain areas, for example, tourist objects [Moes and Fahmi, 2012]. There are 8 BST Corridors with 159 bus fleets in 2015 serving the community [Badan Pusat Statistik, 2016]. However, until now only 4 BST corridors are actively serving. The routes for the four corridors are Corridor 1 (Adi Sumarmo Airport - Palur Bus station), Corridor 2 (Kerten Bus station - Palur Bus station),
Corridor 3 (Kartosuro Bus station - Bundaran Pandawa), and Corridor 4 (Kartosuro Bus station - Palur Bus station via Tirtonadi Bus station) [Dinas Pariwisata Kota Surakarta 2020]. These routes have bus stops close to tourist destinations in Surakarta City which will be described in Table 1, Table 2, Table 3 , and Table 4 for each corridor. In addition, there was other tourist transportation besides BST which are specifically used for tours such as the Werkudara tour bus, tourist horse carriage, Becak, the Bengawan Abiyasa disabled tour bus, the ancient Kluthuk Jaladara train, and the Kresna Batara Railbus but this tourist transportation only operates on certain hours or days and requires a reservation. Meanwhile, BST, which is a public transportation, operates every day. Tourists can take advantage of BST without having to make a reservation and access to BST stops is also available in locations such as stations, terminals, airports, hotels and restaurants which of course support accessibility in travelling. 
Table 1: BST Route Corridor 1 (Adi Soemarmo Airport - Palur Bus Station)

\begin{tabular}{|c|c|c|c|}
\hline $\begin{array}{l}\text { Adi Soemarmo } \\
\text { Airport - Palur } \\
\text { Bus Station }\end{array}$ & $\begin{array}{l}\text { Location of Tourism } \\
\text { Object }\end{array}$ & $\begin{array}{l}\text { Palur Bus } \\
\text { Station - Adi } \\
\text { Soemarmo } \\
\text { Airport }\end{array}$ & $\begin{array}{l}\text { Location of Tourism } \\
\text { Object }\end{array}$ \\
\hline $\begin{array}{ll}\text { Adi } & \text { Soemarmo } \\
\text { Airport } & \end{array}$ & De'Tjolomadoe & Palur Bus Station & - \\
\hline Jl Ahmad Yani & $\begin{array}{l}\text { Kleco Traditional Market, } \\
\text { Solo Square Mall }\end{array}$ & Ir Sutami Road & 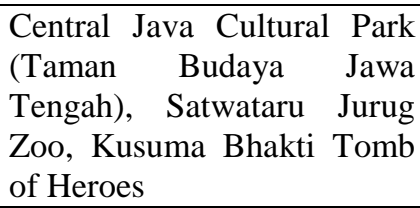 \\
\hline J1 Slamet Riyadi & $\begin{array}{l}\text { Purwosari Train Station, } \\
\text { Solo Grand Mall, Loji } \\
\text { Gandrung Mayor's home } \\
\text { office, R. Maladi Stadion, } \\
\text { Keris Museum, Radia } \\
\text { Pustaka Museum }\end{array}$ & $\begin{array}{ll}\text { J1 } & \text { Koloner } \\
\text { Sutarto } & \end{array}$ & $\begin{array}{ll}\text { Tirtomoyo } & \text { Jebres } \\
\text { Swimingpool } & \end{array}$ \\
\hline $\begin{array}{ll}\text { J1 } & \text { Jenderal } \\
\text { Sudirman } & \end{array}$ & $\begin{array}{l}\text { Gladak, PGS } r \text { Market, } \\
\text { Alun-alun Lor (Lor } \\
\text { Square), Fort Vastenburg }\end{array}$ & $\begin{array}{ll}\text { Jl } & \text { Urip } \\
\text { Sumoharjo } & \end{array}$ & $\begin{array}{l}\text { Gedhe Traditional Market, } \\
\text { Ledoksari } \\
\text { Market, Solo Jebres Train } \\
\text { Station }\end{array}$ \\
\hline J1 Urip Sumoharjo & $\begin{array}{l}\text { Gedhe Traditional Market, } \\
\text { Ledoksari } \quad \text { Traditional } \\
\text { Market, Jebres Train } \\
\text { Station }\end{array}$ & $\begin{array}{ll}\text { Jl } & \text { Kapten } \\
\text { Mulyadi } & \end{array}$ & $\begin{array}{l}\text { PGS Market, Djoeang'45 } \\
\text { building, Jami Assagaf } \\
\text { Mosque, Riyadh Mosque }\end{array}$ \\
\hline J1 Kolonel Sutarto & $\begin{array}{ll}\text { Tirtomoyo } & \text { Jebres } \\
\text { Swimingpool } & \\
\end{array}$ & Jl Veteran & Alun - Alun Kidul \\
\hline J1 Ir. Sutami & $\begin{array}{l}\text { Central Java Cultural Park } \\
\text { (Taman Budaya Jawa } \\
\text { Tengah), Satwataru Jurug } \\
\text { Zoo, Kusuma Bhakti } \\
\text { Tomb of Heroes }\end{array}$ & J1 Bhayangkara & $\begin{array}{l}\text { Museum Keris Solo, R. } \\
\text { Maladi Stadion, }\end{array}$ \\
\hline Palur Bus Station & - & J1 Radjiman & 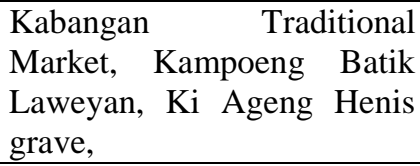 \\
\hline- & - & $\mathrm{J} 1 \mathrm{~W}$ Whidin & \\
\hline - & - & J1 Slamet Riyadi & $\begin{array}{l}\text { Omah Lowo Reservation, } \\
\text { Solo Square Mall, }\end{array}$ \\
\hline- & - & Jl Ahmad Yani & - \\
\hline - & - & $\begin{array}{l}\text { Kartasura Bus } \\
\text { Station }\end{array}$ & - \\
\hline- & - & $\begin{array}{l}\text { Adi Soemarmo } \\
\text { Airport }\end{array}$ & - \\
\hline
\end{tabular}

Table 2: BST Route Corridor 2 (Kartasura Bus Station - Palur Bus Station, Shuttle)

\begin{tabular}{|l|l|}
\hline \multicolumn{1}{|c|}{$\begin{array}{c}\text { Kartasura Bus Station - Palur Bus Station, } \\
\text { Shuttle }\end{array}$} & Location of Tourism Object \\
\hline Kartasura Bus Station & - \\
\hline Jl Ahmad Yani & - \\
\hline Jl Slamet Riyadi & $\begin{array}{l}\text { Purwosari Train Station, Omah Lowo } \\
\text { Reservation }\end{array}$ \\
\hline J1 Doctor Moewardi & Kota Barat Field \\
\hline
\end{tabular}




\begin{tabular}{|l|l|}
\hline J1 Yosodipura & $\begin{array}{l}\text { Solo Paragon Mall, Monumen and Museum } \\
\text { Pers, }\end{array}$ \\
\hline J1 Gajamada & Solo Balapan Train Station \\
\hline J1 Monginsidi & Tirtomoyo Jebres Swimingpool \\
\hline J1 Kolonel Sutarto & $\begin{array}{l}\text { Central Java Cultural Park (Taman Budaya } \\
\text { Jawa Tengah), Satwataru Jurug Zoo, Kusuma } \\
\text { Bhakti Tomb of Heroes }\end{array}$ \\
\hline J1 `Ir. Sutami & - \\
\hline Palur Bus Station & \\
\hline
\end{tabular}

Table 3: BST Route Corridor 3 (Palur Bus Station - Kartasura Bus Station via Klewer Market)

\begin{tabular}{|c|c|c|c|}
\hline $\begin{array}{c}\text { Palur Bus Station - } \\
\text { Kartasura Bus } \\
\text { Station via Klewer } \\
\text { Market }\end{array}$ & $\begin{array}{l}\text { Location of Tourism } \\
\text { Object }\end{array}$ & $\begin{array}{l}\text { Palur Bus Station - } \\
\text { Adi Soemarmo } \\
\text { Airport }\end{array}$ & $\begin{array}{l}\text { Location of Tourism } \\
\text { Object }\end{array}$ \\
\hline Palur Bus Station & - & $\begin{array}{ll}\text { Kartasura } & \text { Bus } \\
\text { Station } & \end{array}$ & - \\
\hline Jl KH Maskur & $\begin{array}{l}\text { Jurug Fruit Market, } \\
\text { Educational Park Jebres, } \\
\text { Solo Technopark }\end{array}$ & \begin{tabular}{|lr} 
Makamhaji & $(\mathrm{J} 1$ \\
Slamet & Riyadi \\
Kartasura $)$ & \\
\end{tabular} & - \\
\hline J1 Kolonel Sutarto & $\begin{array}{ll}\text { Tirtomoyo } & \text { Jebres } \\
\text { Swimingpool } & \end{array}$ & J1 Radjiman & \begin{tabular}{|lr} 
Klewer & Market, \\
Singosaren & Market, \\
Kembang Flower Market, \\
Kampoeng & Batik \\
Laweyan, & Kabangan \\
Traditional & Market, \\
Jongke Tradional Market
\end{tabular} \\
\hline Jl Urip Sumoharjo & $\begin{array}{l}\text { Solo Jebres Train } \\
\text { Station, Ledoksari } \\
\text { Traditional Market }\end{array}$ & Jl Bayangkara & - \\
\hline \begin{tabular}{|l|} 
J1 Jenderal Sudirman \\
\end{tabular} & $\begin{array}{lr}\text { Gedhe } & \text { Tradisional } \\
\text { Market, Gladak, PGS } \\
\text { Market, } & \text { Alun-alun } \\
\text { Utara, } & \text { Kraton } \\
\text { Kasunanan } & \text { Surakarta, } \\
\text { Ki Gedhe Solo Tomb, } \\
\text { Museum Kraton }\end{array}$ & J1 Veteran & $\begin{array}{l}\text { Alun - Alun Kidul / Kidul } \\
\text { Square }\end{array}$ \\
\hline Jl Radjiman & $\begin{array}{lr}\text { Klewer } & \text { Market, } \\
\text { Singosaren } & \text { Market, } \\
\text { Kembang } & \text { Flower } \\
\text { Market, } & \text { Kampoeng } \\
\text { Batik } & \text { Laweyan, } \\
\text { Kabangan } & \text { Traditional } \\
\text { Market, } & \text { Jongke } \\
\text { Tradional Market } \\
\end{array}$ & J1 Kapten Mulyadi & $\begin{array}{l}\text { PGS Market, Jami } \\
\text { Assagaf Mosque, Riyadh } \\
\text { Mosque }\end{array}$ \\
\hline $\begin{array}{l}\text { Makamhaji (Jl Slamet } \\
\text { Riyadi Kartasura) }\end{array}$ & - & J1 Mayor Kusmanto & Fort Vastenberg \\
\hline Kartasura Bus Station & - & J1 Jenderal Sudirman & $\begin{array}{l}\text { Fort Vastenberg, Gladak, } \\
\text { PGS Market, Alun-alun } \\
\text { Utara, }\end{array}$ \\
\hline & - & J1 Urip Sumoharjo & $\begin{array}{|lr|}\text { Gedhe } & \text { Traditional } \\
\text { Market, } & \text { Gedhe } \\
\text { Traditional } & \text { Market, } \\
\text { Ledoksari } & \text { Traditional } \\
\end{array}$ \\
\hline
\end{tabular}




\begin{tabular}{|l|l|l|l|}
\hline & & & $\begin{array}{l}\text { Market, Solo Jebres Train } \\
\text { Station }\end{array}$ \\
\hline- & - & J1 Kolonel Sutarto & $\begin{array}{l}\text { Tirtomoyo Jebres } \\
\text { Swimingpool }\end{array}$ \\
\hline- & & J1 KH Maskur & $\begin{array}{l}\text { Jurug Fruit Market, } \\
\text { Educational Park Jebres, } \\
\text { Solo Technopark }\end{array}$ \\
\hline
\end{tabular}

Table 4: BST Route Corridor 4 (Kartasura Bus Station - Solo Baru)

\begin{tabular}{|l|l|l|l|}
\hline $\begin{array}{l}\text { Kartasura Bus } \\
\text { Station - Solo Baru } \\
\text { Tugu Cemberengan) }\end{array}$ & $\begin{array}{l}\text { Location of Tourism } \\
\text { Object }\end{array}$ & $\begin{array}{l}\text { Solo Baru (Tugu } \\
\text { Cembengan) - } \\
\text { Kartasura Bus } \\
\text { Station }\end{array}$ & Tourist sites \\
\hline Kartasura Bus Station & Bundaran Pandawa & - \\
\hline J1 Adi Sucipto & $\begin{array}{l}\text { De'Tjolomadoe, } \\
\text { Manahan Stadion, }\end{array}$ & Grogol & - \\
\hline J1 Dr. Moewardi & Kota Barat Field & J1 Brigjen Sudiarto & - \\
\hline J1 Yosodipuro & $\begin{array}{l}\text { Solo Paragon Mall, } \\
\text { Monumen and Museum } \\
\text { Pers }\end{array}$ & J1 Veteran & Alun - Alun Kidul \\
\hline J1 Gajah Mada & & J1 Yos Sudarso & - \\
\hline J1 Honggowongso & Kembang Market, & J1 Slamet Riyadi & - \\
\hline J1 Veteran & Alun - Alun Kidul & J1 Jenderal Sudirman & - \\
\hline J1 Brigjen Sudiarto & - & J1 Ronggowarsito & Pura Mangkunegaran \\
\hline J1 KH Wahid Hasyim & - & J1 Dr Soepomo & \\
\hline Bundaran Pandawa & - & J1 Yosodipuro & $\begin{array}{l}\text { Solo Paragon Mall, } \\
\text { Monumen and } \\
\text { Museum Pers }\end{array}$ \\
\hline- & - & $\begin{array}{l}\text { De'Tjolomadoe, } \\
\text { Manahan Stadion, }\end{array}$ \\
\hline- & - & J1 Adi Sucipto & - \\
\hline
\end{tabular}

Herman Moeis and Ali Fahmi researched transportation services that can attract tourists and the result was that accessibility is a very important factor making it easier for tourists to get to tourist objects. [Moes and Fahmi, 2012]. As seen in Table 1 to Table 4, there were quite a lot of tourist attractions /objects that can be reached by BST and of course, BST can or can be used by tourists. During the use ofBST, tourists can also see the sights of the city of Surakarta. Even though the city of Surakarta is not big, many spots can be seen and enjoyed when travelling on BST. For example on BST corridor 1, tourists can enjoy the view along J1. Slamet Riyadi, which is the main location for city branding, where there are city walks, parks, and railways in the middle of the city that are still functioning, are used for tourist transportation for the Kluthuk Jaladara train, and the Kresna Batara Railbus. On BST Corridor 2, tourists can enjoy views of the denser northern side of the city. Then with BST Corridor 3, tourists will be spoiled by historical tourist spots such as the North Square area, Surakarta Palace, Klewer Market, and also one of the shopping centres in Surakarta along Jl. General Sudirman. For BST Corridor 4 covers the North and South areas where tourists can see tourist spots in Sukoharjo and Boyolali regency.

From the description of the BST route for each corridor, it can be seen that apart from tourist objects, BST itself was also integrated with other public transportation. BST connects Solo Balapan Train Station, Purwosari Train Station, Tirtonadi Bus Station, Adi Soemarmo Airport, Palur Bus Station in Karanganyar, and Bus Kartosuro Station in Sukoharjo. From the survey results, 
$79 \%$ of the people of Surakarta state that public transportation in Surakarta city was integrated and $71 \%$ of the people state that there was an effort by the city government in realizing integrated public transportation [Anandhita, 2019]. Of course, with the integration of other public transportation with $\mathrm{BST}$, it will make the mobility of tourists easier.

\section{Preference of BST Payment Systems that Support the Tourism Sector}

Ease of transactions in modern times is very important, especially in this case as a means of payment for transportation. The city government of Surakarta has adopted the BST bus ticket payment method with banking electronic money cards such as BRIZZI
(BRIZZI (Bank BRI), TapCash (Bank BNI), e-Money (Bank Mandiri), Flazz (Bank BCA) and e-Bima (Bank Jateng) [Batik Solo Trans, 2020]. However, a study in 2012 stated that $50 \%$ of electronic money card users were unsatisfied with technical problems [Veranita YM Suratno, 2012]. In the end, the payment system did not work and BST ticket purchases were back manually. Researchers surveyed the types of payment systems that were possible to attract users, especially tourists. Four system options were given and 100 respondents were asked to choose the most preferred payment system. Figure 5 shows the results of an analysis of the types of payment systems that tourists were interested in.

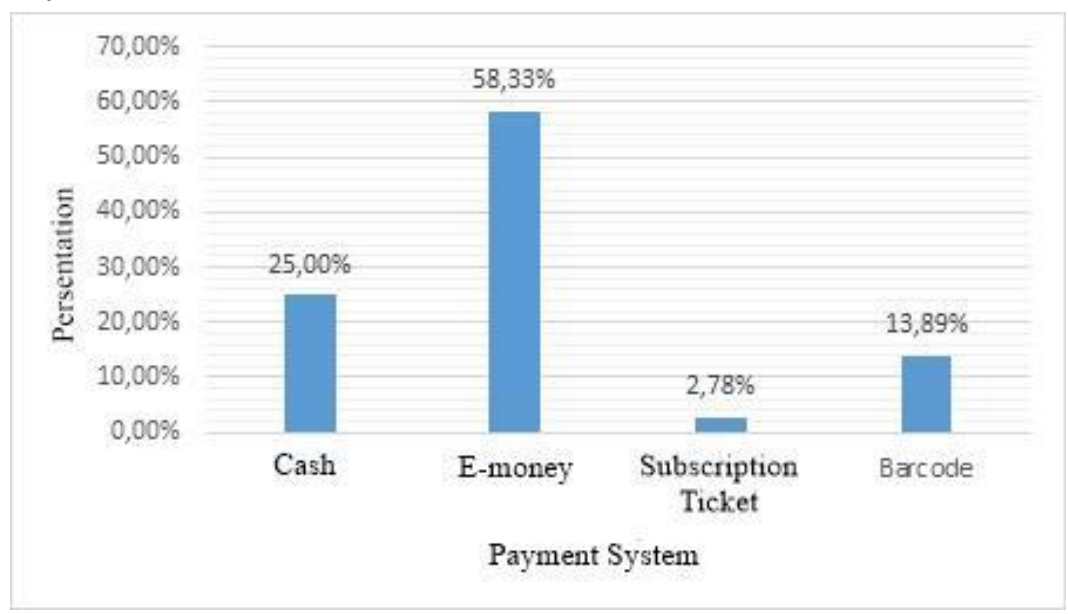

Figure 5: The most popular payment systems (Analisis, 2020)

The results showed that $58.33 \%$ of tourists were more interested in payment systems using tap cash or electronic money cards and $25 \%$ of tourists still prefer direct or manual payments. This shows that the payment system using electronic money cards is more attractive to tourists because it is considered to be easy and safe in transactions where it allows tourists not to carry too much cash. Besides that, by using electronic money cards tourists do not need to exchange money manually because they only need to fill in the electronic money cards. Research by Veranita YM Suratno shows that dissatisfaction with equipment was carried out in 2012 where the use of e-money was still not as much as it is today. Surakarta City government will once again in 2020 activate the use of electronic money cards in the BST payment system and also collaborate with the "Teman Bus" service, which is an application that can be downloaded on the Playstore and Appstore where this application will help prospective passengers get route information for stop points and schedules bus departure [Pemerintah Kota Surakarta, 2020]. This preference for using an electronic money card can certainly support the tourism factor in Surakarta City because it can also be used as a safe and efficient way of non-cash payment when purchasing tickets to enter tourist areas in Surakarta, considering that this electronic money card collaborates with several programs in well-known banks in Indonesia, such as Tap Cash BNI, flazz BCA, MANDIRI e-money, and BRI brizzi, which currently quite easy to fill and use simply by sticking the card on the reader. 


\section{Conclusion}

Batik Solo Trans was a public transportation in Surakarta city which includes many locations of Tourism Objects in Surakarta city. There were 4 active corridors that can be used by tourists as well as the "Solo Destination" and "Teman Bus" applications which further facilitate transportation accessibility in Surakarta City. The payment system using a Non-Cash Card in collaboration with Tap Cash BNI, BCA flazz, MANDIRI e-money, and BRI brizzi provides convenience in transactions and of course can increase income and greatly support the tourism sector in Surakarta City supported by research results $58.33 \%$ of travelers prefer to use electronic money cards or cashless.

\section{Acknowledgements}

The support of Surakarta City government program in improving Batik Solo Trans (BST) services was very helpful in making this paper and it was hoped that Surakarta City government can further develop the transportation sector that can support improvements in the tourism sector in Surakarta.

\section{Literature References}

Badan Pusat Statistik. (2016). Kota

Surakarta Dalam Angka 2016. Surakarta: BPS Kota Sukarta.

Batik Solo Trans. (2020).Wikipedia, Ensiklopedia Bebas. Diakses pada 05:59, Juni 23, 2020, from https://id.wikipedia.org/w/index.ph p?title=Batik_Solo_Trans\&oldid=171 01875.

Dinas Pariwisata Kota Surakarta. (2020). Batik Solo Trans [Online] Available : https://pariwisatasolo.surakarta.go.i d/destinations/batik-solo-trans/ [2020, November 13].

Dinas Perhubungan Kota Surakarta. (2012). Tatralok Kota Surakarta 2009. Kota Surakarta.

Mustika, H. (2017). Peran Serta Stakeholder Dalam Membentuk City Branding The Spirit Of Java di Jalan Slamet Riyadi
Surakarta. JURNAL PEMBANGUNAN

WILAYAH \& KOTA, 13(1), 67-82. ISSN: 1858-3903

Moeis, H., \& Fahmi, A. (2012). Model Layanan Transportasi Untuk Menarik Minat Wisatawan Berkunjung Ke Objek Wisata Di Jawa Timur. Governance Jurnal Kebijakan dan Manajemen Publik, 3(1), 24-34.

Nugroho, R. A., Santoso, E. B., \& Susetyo, C. (2019). Konsep Manajemen Trans Batik Solo sebagai Pendukung Sektor Pariwisata di Kota Surakarta. Jurnal Manajemen Aset Infrastruktur \& Fasilitas, 3(1).

Pemerintah Kota Surakarta. (2020). Layanan Teman Bus [Online] Available: https://surakarta.go.id/?p=17152 [2020, November 13].

Pratiwi, D. I., Harsasto, P., \& Herawati, N. R. (2015). Networking dalam Program Pelayanan Transportasi Batik Solo Trans di Kota Surakarta. Journal of Politic and Government Studies, 4(3), 111-120.

Setyowati, K., \& Astriyani, T. (2017). InterGovernmental Relation in City Bus Public Transportation Service in Surakarta in Indonesia (No. jmmr164). Global Academy of Training and Research (GATR) Enterprise.

Suratno, V. Y. M., \& Kurniawan, A. (2013). Kajian tingkat efektivitas penggunaan eticketing oleh penumpang batik solo trans di surakarta dan sekitarnya. Jurnal Bumi Indonesia, 2(3).

Yulianto, B., Legowo, S. J., \& Atmojo, M. S. (2017). Analisis Potensi Demand Pada Sekolah Serta Ability To Pay (ATP) dan Willingness To Pay (WTP) Pada Batik Solo Trans (BST) Koridor Empat Di Surakarta. Matriks Teknik Sipil, 5(3).

Yuliarti, M. S., Hastjarjo, S., \& Anggreni, L. S. (2017, November). Smart City and Diffusion of Innovations Process: Communicating "Solo Destination" as IoT Implementation of Smart City in Surakarta. In 3rd International Conference on Transformation in Communications 2017 (IcoTiC 2017). Atlantis Press. ISSN: 2352-5398 